\author{
ks. Stanisław Gruca SCJ \\ Sosnowiec \\ ORCID: 0000-0003-3744-517X; e-mail: staszekscj@wp.pl \\ https://doi.org/10.4467/25443283SYM.20.002.12119
}

\title{
WPŁYW ŚW. MAŁGORZATY MARII ALACOQUE NA DUCHOWOŚĆ ZGROMADZENIA KSIĘŻY NAJŚWIĘTSZEGO SERCA JEZUSOWEGO
}

\section{AN IMPACT OF SAINT MARGARET MARY ALACOQUE ON THE SPIRITUALITY OF THE CONGREGATION OF THE PRIESTS OF THE SACRED HEART OF JESUS}

\begin{abstract}
Abstrakt
Artykuł ukazuje wpływ przesłania św. Małgorzaty Marii Alacoque na duchowość Zgromadzenia założonego przez sługę Bożego o. Leona Dehona. Analiza podjętej problematyki składa się z trzech części. Omówienie podobieństwa duchowego oraz zbieżności niektórych etapów życia o. Dehona i św. Małgorzaty Marii Alacoque składają się na cześć pierwszą. W następnej wyeksponowany zostaje wpływ świętej z Paray-le-Monial na kształtowanie duchowości Zgromadzenia Księży Najświętszego Serca Jezusowego w czasach o. Dehona. Ostatnia część ukazuje łączność duchową Zgromadzenia ze spuścizną świętej wizytki i jej aktualizację we współczesności. Bezpośrednie idee założenia Zgromadzenia o charakterze wynagradzającym o. Dehon czerpał nie tylko z objawień przekazanych św. Małgorzacie
\end{abstract}


Marii Alacoque. W jego spuściźnie pisarskiej można odnaleźć osobiste doświadczenie miłości Bożego Serca i wprowadzanie wszystkich elementów nabożeństwa ku Jego czci w nowopowstałym dziele. Końcowy etap krystalizowania duchowości Zgromadzenia odsłonił pełne dynamizmu spojrzenie o. Dehona na kult Serca Jezusowego, reinterpretację istoty tego kultu oraz jego akomodację w zmieniającej się rzeczywistości. Przesłanie z Paray-le-Monial nadal znajduje swój wyraźny ślad w dokumentach normatywnych Instytutu.

Wpływ św. Małgorzaty Marii Alacoque na duchowość Zgromadzenia Księży Najświętszego Serca Jezusowego zawsze był wyraźny i stanowił źródło inspiracji dla kolejnych pokoleń sercanów. Obecnie przesłanie z Paray-le-Monial należy odczytywać w kluczu „dynamicznej wierności” charyzmatowi Założyciela.

Słowa kluczowe: Leon Dehon, Małgorzata Maria Alacoque, objawienia, Serce Jezusa, miłość, wynagrodzenie, ofiara, cierpienie, charyzmat

\section{Abstract}

The article presents an impact of the message of Saint Margaret Mary Alacoque on the spirituality of the Congregation founded by servant of God Father Leon John Dehon. Analysis of the addressed issue consists of three parts. The first part will touch the periphrasis of the spiritual parallels and concurrence of some of the stages of life of Fr. Dehon and saint Margaret Mary. In the next part the influence of the saint from Paray le Monial on the development of the spirituality of the institute during the time of Fr. Dehon will be underlined. The last part will show the spiritual connection of the Congregation with the legacy of the saint from Paray le Monial and its actualization in the contemporary world.

The immediate ideas of founding Congregation that has the reparation as one of its feature Fr. Dehon drew not only from the revelations of Saint Margaret Mary. In his writing works one can find his personal experience of love of the Sacred Heart and introduction of all the elements of unction towards God in his newly establish religious community. The final stage of crystallization of the spirituality of the Congregation revealed full of dynamism view of Fr. Dehon on the cult of Jesus' Heart, reinterpreta- 
tion of the core of such cult and its location in the ever changing reality. The message from Paray le Monial still finds its clear mark in the normative documents of the Institute.

The influence of Saint Margaret Mary Alacoque on the spirituality of the Congregation of the Priests of the Sacred Heart of Jesus has always been distinct and constituted a source of inspiration for consecutive generations of Dehonians. At present the message from Paray le Monial should be viewed in the context of "dynamic fidelity" to the charism of the Founder.

Keywords: Leon John Dehon, Margaret Mary Alacoque, revelations, Heart of Jesus, love, reparation, sacrifice suffering, charism

Obecnie przeżywany rok w Polsce i w Kościele jest bogaty w rocznice i jubileusze. Tylko w kontekście samego kultu Najświętszego Serca Jezusowego należy zauważyć dwa ważne wydarzenia: stulecie poświęcenia ojczyzny Najświętszemu Sercu Jezusa (27 lipca) oraz wyniesienia na ołtarze św. Małgorzaty Marii Alacoque (13 maja).

Papież Benedykt XV, który dokonał aktu kanonizacji św. Małgorzaty Marii Alacoque, w jednym z przemówień zauważył, że przybliżyła ona prawdę o Bogu, który kocha i pragnie być kochanym. Porównał jej misję do „świtu, zapowiadającego tak upragnione południe, w którym panowanie Jezusa Chrystusa zostanie przez wszystkich rozpoznane" ${ }^{\text {. Za- }}$ łożyciel Zgromadzenia Księży Najświętszego Serca Jezusowego o. Leon Dehon (1843-1925) powrócił do przesłania z Paray-le-Monial. Odniósł go do własnego życia, a następnie istotne elementy tego przesłania włączył w duchowość swojego Zgromadzenia. Ostatnie lata przygotowań do kanonizacji św. Małgorzaty Marii Alacoque były dla Założyciela głębokim przeżyciem oraz swoistym wynagrodzeniem za wytężoną pracę na rzecz utrwalania cywilizacji miłości Bożego Serca. W 1918 roku podczas ceremonii potwierdzenia objawień świętej z Paray-le-Monial o. Dehon

${ }^{1}$ La glorificazione della B. Margherita Alacoque e la propagazione del culto del S. Cuore, „La Civiltà cattolica” 1(69) (1918), s. 144. 
został wyróżniony i otrzymał bilet w pierwszym rzędzie auli ${ }^{2}$. Z wielkim zadowoleniem przyjął również decyzję ojca świętego o umieszczeniu w bazylice Świętego Piotra w Rzymie ołtarza poświęconego Sercu Jezusa i św. Małgorzacie Marii Alacoque. W tworzeniu projektu tego ołtarza miał on osobisty udział. W liście okólnym do Zgromadzenia ujawnił motywy i szczegóły projektu ołtarza oraz jego lokalizację w bazylice Świętego Piotra. Kończąc list, wyraził zachętę, ażeby jego duchowi synowie często wracali do przesłania obrazu, w którym „nasz Pan w lewej ręce ukazuje swoje Serce, a prawą rękę otwiera, aby żebrać. Jezus wydaje się nam mówić: "Oto daję wam moje Serce, ale z kolei wy oddajcie mi swoje»" ${ }^{3}$ Parafrazując myśl papieża Benedykta XV, można powiedzieć, że o. Dehon przyczynił się do tego, aby świt związany z misją św. Małgorzaty Marii Alacoque stał się rychło światłem południa, w którym cywilizacja miłości Bożego Serca ogarnie świat.

\section{Elementy zbieżne w życiu św. Małgorzaty Marii Alacoque i o. Leona Dehona}

Podjęta w tym punkcie próba powiązania biografii dwóch osób żyjących w różnych epokach nie ma na celu wyłonienia za wszelką cenę ich podobieństw, ale chodzi raczej o pokazanie działania Bożego, zmierzającego do urzeczywistnienia w historii Jego woli. Zresztą w biografii

2 Por. M. Denis, Projekt o. Dehona, Kraków 1990, s. 309. Wielką łaską dla o. Dehona był również pontyfikat Benedykta XV. Nowego papieża określił mianem przyjaciela, odważnego biskupa, który wspierał poświęcenie rodzin swojej diecezji Bożemu Sercu, oraz papieża pokoju, misji i Najświętszego Serca Jezusowego. Por. L. Dehon, La revue catholique des idées et des faits, Benoît XV intime, 10 février 1922 r., http://www.dehondocsoriginals.org/ pubblicati/ART/REV/ART-REV-1922-0200-0004309? ch=10 (odczyt z dn. 02.05.2020 r.). Por. także: TENŻE, Notes quotidiennes, http://www.dehondocsoriginals.org/pubblicati/JRN/ NQT (odczyt z dn. 02.05.2020 r.) (dalej: NQT), XXXV/1913, 90.

3 „Dans ces images, Notre Seigneur présente son Couur dans sa main gauche et sa main droite souvre pour mendier. Jésus semble nous dire; «Tiens, je te donne mon Cœur, mais à ton tour donne-moi le tien»". L. Dehon, Lettres circulaires, http://www.dehondocsoriginals.org/pubblicati/COR/LCC (odczyt z dn. 02.05.2020 r.) (dalej: LCC), 17 février 1918. Por. NQT, XXXV/1913, 90. 
o. Dehona często można spotkać biogramy świętych, którzy poprzez określony styl życia, trudności lub wybory życiowe stają się mu bliskimi do tego stopnia, że w ich sposobie życia widzi siebie. Przykładem są betlejemskie dzieci, św. Stanisław Kostka, św. Alojzy Gonzaga lub św. Jan Berchmans ${ }^{4}$. Sam Założyciel w życiorysie św. Małgorzaty Marii Alacoque dostrzega raczej pokrewieństwo duchowe, związane z kultem Serca Jezusowego, niż podobieństwo na poziomie historii życia.

\section{a) Doświadczenie wybrania i poświęcenie się Bogu}

Święta Małgorzata Maria Alacoque urodziła się 22 lipca 1647 roku w Lhautecour w zamożnej rodzinie Klaudiusza i Filiberty Alacoque. We wczesnej młodości została oddana na wychowanie dwóm służącym. Z okresu dziecięctwa pochodzi również ślub poświęcenia życia w dziewictwie i oddania się na wyłączność Chrystusowi. Bóg wzbudził w niej silne upodobanie do czystości i to do tego stopnia, że jako dziecko nie w pełni świadome znaczenia słów powtarzała wezwanie: „Mój Boże, poświęcam Ci moją czystość i ślubuję wieczyste dziewictwo" ${ }^{5}$. Podobny poryw ducha przeżył o. Dehon, gdyż został oddany na wychowanie do kolegium w Hazebrouck. Wówczas głębokim przeżyciem duchowym było dla niego doświadczenie Bożej miłości podczas Mszy Świętej pasterskiej 24 grudnia 1856 roku. Wtedy odkrył w sercu głos powołania i Boże żądanie, aby Mu się całkowicie poświęcić 6 .

4 Por. NQT V/1891, 65r-71v.

5 Por. Benedykt XV, Przedziwna historia. Bulla kanonizacyjna bł. Małgorzaty Marii Alacoque, dziewicy, siostry profeski Zakonu Nawiedzenia Najświętszej Maryi Panny, Kraków 2017, s. 6-7.

6 Zawsze będzie wspominał kolegium w Hazebrouck jako miejsce wyjątkowe: „Doznałem tam jednego z największych wrażeń w życiu. Jezus przynaglił mnie mocno, abym Mu się oddał. Dziękczynienie trwało we mnie tak mocno, że miałem przez długi czas wrażenie, iż moje nawrócenie dokonało się właśnie tamtego dnia”. L. DEHoN, Notes sur l'histoire de ma vie, http://www.dehondocsoriginals.org/pubblicati/JRN/NHV (odczyt z dn. 03.05.2020 r.) (dalej: NHV) I, 26r. Por. także: H. Dorresteijn, Vita e personalità di Padre Dehon, Bologna 1978, s. 26-31. 


\section{b) Trudności w wyborze powołania}

Innym podobieństwem obu postaci był sprzeciw rodziny wobec wyboru drogi powołania. Okres szczęśliwego życia św. Małgorzaty Marii Alacoque zakończył się wraz z wczesną śmiercią ojca. Dziewczyna została oddana na wychowanie do sióstr klarysek w Charolles. Zapragnęła na zawsze zostać zakonnicą, ale przeszkodziła jej w tym tajemnicza choroba. Przez cztery lata pozostawała w łóżku i była tak słaba, że nie mogła chodzić. Wówczas jej matka postanowiła ofiarować ją Maryi z obietnicą, że jeżeli dziecko wyzdrowieje, to zostanie Jej poświęcone. Po cudownym uleczeniu dziewczynka faktycznie oddała się Maryi i przyjęła Ją za swoją przewodniczkę. Po kilku latach rodzina zapomniała o złożonej obietnicy, a św. Małgorzata Maria Alacoque również miewała rozterki związane z wyborem drogi życia. Codzienność przeżywała zwyczajnie, była dziewczyną o radosnym usposobieniu do tego stopnia, że niektórzy wątpili w jej powołanie. Lubiła pomagać chorym, często uczęszczała na Mszę Świętą. Ostatecznie, mimo sprzeciwu ze strony rodziny, udało się jej wstąpić do klasztoru. Od chwili przekroczenia furty klasztornej 20 czerwca 1671 roku odnalazła pokój serca, a Chrystus mógł działać w jej duszy ${ }^{7}$.

Ojciec Leon Dehon również pochodził z zamożnej rodziny. Po doświadczeniu Boga w Hazebrouck zapragnął zostać kapłanem. Decyzji wstąpienia do seminarium sprzeciwiał się przede wszystkim ojciec, ale zawiodła go też roztropna i pobożna matka. Ojciec przewidywał dla syna karierę adwokacką lub dyplomatyczną. Ponieważ jako nieletni nie mógł decydować o sobie, a równocześnie chciał zadowolić ojca, odłożył decyzję wstąpienia do seminarium na czas po zakończeniu studiów. Po studiach wyjazd do Francuskiego Seminarium w Rzymie i tak okazał się trudny, bo o. Leon Dehon wciąż nie miał akceptacji rodziców. Wiedział jednak, że tylko w ten sposób będzie mógł zrealizować wolę Jezusa ${ }^{8}$.

\footnotetext{
7 Por. Benedykt XV, Przedziwna historia..., dz. cyt., s. 7-10.

8 Por. NHV I, 37r-41v; NHV IV, 102-103.
} 


\section{c) Posłuszeństwo, pokora i pokonywanie trudności}

Najbardziej charakterystycznym rysem łączącym św. Małgorzatę Marię Alacoque i o. Leona Dehona była jednak postawa pokory i posłuszeństwa wobec przełożonych oraz znoszenie cierpień. Święta wizytka po złożeniu profesji zakonnej zapisała własną krwią postanowienia, które zamierzała realizować w ciągu całego życia: „Nic nie zachowywać dla siebie, we wszystkim należeć do Boskiego Oblubieńca”. Chwile szczególnego bólu przeżywała wtedy, gdy Chrystus domagał się od niej wyraźnego nabożeństwa ku czci swojego Serca. Lata 1673-1675 to okres tzw. wielkich objawień, w których Boski Oblubieniec przekazywał skromnej zakonnicy najgłębsze tajemnice swojego Serca. Prosił ją również, ażeby we wszystkim pozostawała posłuszna woli przełożonych. Przykrym doświadczeniem dla św. Małgorzaty Marii Alacoque był proces stwierdzenia wiarygodności jej objawień, który przeprowadzili doświadczeni kierownicy duchowi. Po jego zakończeniu zakonnicy ci przekazali matce przełożonej opinię, że siostra Małgorzata pozostaje w złudzeniu duchowym $^{9}$. W późniejszej korespondencji ze swoją przełożoną matką Franciszką de Saumaise, św. Małgorzata Maria Alacoque odsłania swoje przeżycia duchowe płynące z przyjmowania krzyża i upokorzeń: „To, co kocham najbardziej, poza Nim samym, to cenny skarb Jego krzyża, towarzyszący mi wewnętrznie i zewnętrznie. $Z$ niego płynie jedyna pociecha, jaką mam w tym życiu, które jest mi miłe dlatego, że można w nim cierpieć, znosić cenne upokorzenia, przynoszące zapomnienie i wzgardę ze strony stworzeń" ${ }^{10}$.

Wskazania św. Małgorzaty Marii Alacoque o pokorze, posłuszeństwie i przyjmowaniu cierpień stały się pomocne dla o. Dehona. Po założeniu instytutu Oblatów Najświętszego Serca Jezusowego przystąpił on do pisania konstytucji oraz dyrektorium duchowego. Nie brakowało w tym okresie trudności. Brak płynności finansowej, pożar budynku

9 Por. Benedykt XV, Przedziwna historia..., dz. cyt., s. 14-21.

${ }^{10}$ M. M. Alacoque, Listy św. Małgorzaty Marii Alacoque, tłum. M. K. Piwnicka-Bohuszewicz, Kraków 2009, s. 18-19. W innym liście pisze: „A chociaż w oczach ludzkich zdrowie więcej chwały przynosi Bogu, jednak bez porównania więcej zjednuje Mu cierpienie, bo wtedy jest czas na sianie oraz na podlewanie i uprawianie”. Tamże, s. 31. 
kolegium, choroba i wytężona praca - wszystko to mocno nadwyrężyło jego wątłe zdrowie. Trudne relacje z niektórymi współbraćmi, krytyka wewnątrz zgromadzenia, liczne donosy i komentarze związane z rzekomymi wizjami jednej z sióstr ze Zgromadzenia Służebnic Najświętszego Serca Jezusowego, gdzie był spowiednikiem, doprowadziły do kasaty instytutu oblatów ${ }^{11}$. Decyzję Stolicy Apostolskiej o zniesieniu dzieła o. Dehon określił przy pomocy słów Chrystusa z krzyża - Consummatum est. Mimo tak bolesnego doświadczenia decyzję tę wykonał z wielką ufnością i posłuszeństwem ${ }^{12}$. W swoich notatkach napisał: „Jest to rok Consummatum est, rok straszliwy. Ileż udręk, ileż utrapień! Opuściłem wszystko, oderwałem się od wszystkiego, złożyłem wszystko w ofierze, aby założyć Dzieło wynagrodzenia względem Najświętszego Serca, wszystko: moją karierę księdza diecezjalnego, moje dobra materialne, liczne przyjaźnie, nadzieje i pokój mojej rodziny. Wydawało się, że Bóg przyjął moją ofiarę, udzielając mi wielu łask, a także formalnej zachęty oraz przekazując mi swoje słowo"13.

\section{Wpływ przesłania z Paray-le-Monial na kształtowanie duchowości Zgromadzenia Księży Najświętszego Serca Jezusowego w czasach o. Leona Dehona}

Wiedzę na temat istotnych elementów nabożeństwa do Najświętszego Serca Jezusowego czerpiemy przede wszystkim z autobiografii św. Małgorzaty Marii Alacoque, którą napisała na polecenie swojego spowiednika, oraz z jej bogatej korespondencji. Pierwsze wizje Chrystusa służyły przede wszystkim samej świętej jako drogowskazy w głębszym postępie duchowym. Następnie tzw. cztery wielkie objawienia miały charakter społeczny i odnosiły się do całego Kościoła. W pierwszym objawieniu Chrystus mówił o wielkiej miłości ku św. Małgorzacie Marii Alacoque i ludziom, zamierzając za jej przyczyną ubogacić świat drogocennymi

\footnotetext{
11 Por. M. Denis, Projekt..., dz. cyt., s. 39-40.

12 Por. NHV XIV, 173-183.

13 NHV XIV, 175.
} 
skarbami ${ }^{14}$. Następnie wziął jej serce i zanurzył w swoim, sprawiając, że zapłonęło ono miłością Bożą. Widocznym śladem tamtego przeżycia będzie zapowiedziany przez Jezusa ból w ranie boku, który święta odczuwała przez całe życie ${ }^{15}$. Niedługo po tym widzeniu św. Małgorzata Maria Alacoque otrzymała drugie objawienie. Zobaczyła Serce Jezusa jakby na tronie, otoczone koroną cierniową i z krzyżem na szczycie. Jezus znów mówił o konieczności praktykowania nabożeństwa, które miało być jedynym ratunkiem na ostatnie czasy. Na podstawie tego widzenia został określony przedmiot kultu, którym jest niepojęta miłość Zbawiciela do ludzi, zamknięta w symbolu serca ${ }^{16}$. Trzecie objawienie dokonało się w lipcu 1674 roku. Święta wizytka zobaczyła Zbawiciela oraz jaśniejące rany Jego rąk i nóg. Najjaśniejsza była rana boku. Po otwarciu rany zobaczyła Serce, które ogarnia wszystkich miłością i jest źródłem światła. Jezus skarżył się na niewdzięczność i oziębłość oraz wzgardę otrzymywaną od ludzi. Za te krzywdy domagał się zadośćuczynienia i wynagrodzenia. Określił także praktyki wynagrodzenia, do których należą: częste przystępowanie do Komunii Świętej, zwłaszcza w pierwszy piątek miesiąca, oraz praktyka godziny świętej w nocy z czwartku na piątek ${ }^{17}$. W 1675 roku w oktawie Bożego Ciała dokonało się czwarte objawienie, nazwane „wielkim”. Chrystus, ukazując swoje Serce, wypowiedział znamienne słowa: „Oto Serce, które tak bardzo ukochało ludzi, że w niczym nie oszczędzając siebie, całkowicie się wyniszczyło i ofiarowało, aby im okazać miłość"18. W dalszej części jest mowa o oziębłości, wzgardzie i niewdzięczności, zwłaszcza osób wybranych. Wyjątkowość tego objawienia polega na tym, że Zbawiciel domagał się w nim kultu publicznego oraz

14 „Moje Boskie Serce - powiedział do mnie - jest tak rozpalone miłością do ludzi, a w szczególności do ciebie, że już nie może dłużej tłumić w sobie płomieni tej palącej miłości. Ono chce ją rozlać za twoim pośrednictwem i objawić ją ludziom, by ich ubogacić kosztownymi darami, które ci dopiero ukażęe. M. M. Alacoque, Pamiętnik duchowy, Kraków 2003, s. 90.

15 Por. Tamże, s. 90.

16 Por. C. Drążek, L. Grzebień (red.), Bóg bliski. Historia i teologia kultu Najświętszego Serca Jezusa, Kraków 1983, s. 43. Por. M. M. Alacoque, Pamiętnik..., dz. cyt., s. 92.

17 Por. M. M. Alacoque, Pamiętnik..., dz. cyt., s. 93-95.

18 Tamże, s. 146. 
ustanowienia święta ku czci swego Serca. Chociaż w Kościele nigdy nie brakowało poszczególnych elementów nabożeństwa, zwłaszcza czci i ekspiacji za grzechy względem Boga, to jednak w Paray-le-Monial Chrystus podkreślił wyraźnie i mocno ten obowiązek ${ }^{19}$.

Dla o. Leona Dehona przesłanie z Paray-le-Monial w początkach istnienia Zgromadzenia zajmowało szczególne miejsce. Posiadał on głęboką wiedzę na temat życia świętej, treści objawień, ale i miejsca, które Pan Jezus wybrał sobie na przekazanie orędzia o swojej miłości. W medytacji na temat św. Jana Ewangelisty, zastanawiając się nad motywem, dla którego Bóg wybrał właśnie to niewielkie miasteczko, pisał: „Miałem kolejny raz przyjemność odwiedzić Paray. Uwielbiam jego pobożne sanktuarium Nawiedzenia, bardziej odpowiednie dla prywatnego pielgrzymowania niż dla dużych tłumów. Dlaczego nasz Pan wybrał Paray? Ponieważ jest to serce Francji. To diecezja Autun, gdzie spoczywa święty Łazarz, przyjaciel Najświętszego Serca. Paray miało swoje duże opactwo cystersów, w którym uczniowie świętego Bernarda modlili się do Najświętszego Serca i wzdychali po nadejściu Jego panowania. Paray-le-Monial! To nowy ziemski raj, do którego zszedł Pan i rozmawiał ze swoją służebnicą, podobnie jak uczynił to Bóg z Adamem w ogrodzie z Księgi Rodzaju"20.

W tym samym dziele uzasadnia motyw, dla którego tak mocno czuje się związany z miasteczkiem, w którym żyła św. Małgorzata Maria Alacoque. Oczywiście tym, co łączyło go ze świętą z Paray-le-Monial było Serce Jezusa. Był przekonany, że podobnie jak jej zadaniem było oddawanie czci Boskiemu Sercu Jezusa, tak jego misją miało być powołanie do

19 Por. C. Drążek, L. Grzebień (red.), Bóg bliski..., dz. cyt., s. 43.

20 „J'eus plusieurs fois le bonheur de visiter Paray. J'aime son pieux sanctuaire de la Visitation, plus adapté à des pèlerinages privés quà de grandes foules. Pourquoi Notre Seigneur a-t-il choisi Paray? C'est le cœur de la France. C'est le diocèse d'Autun où repose saint Lazare, l'ami du Sacré Cour. Paray avait sa grande abbaye cistercienne, où les disciples de saint Bernard priaient le Sacré Cœur et soupiraient après la venue de son règne. Paray-le-Monial! C'est le nouveau Paradis terrestre où Notre Seigneur descendait au jardin et s'entretenait avec sa servante, comme Dieu faisait avec Adam au Paradis de la Genèse”. L. Dehon, Études sur le Sacré Cœur de Jésus (dalej: ESC), w: tenże, Euvres Spirituelles, t. 5, Andria 1984, s. 599. 
życia instytutu poświęconego kultowi, wynagrodzeniu i apostolstwu Serca Jezusowego ${ }^{21}$. Z wypowiedzi tej wynika, że na etapie tworzenia Zgromadzenia o. Dehon nie miał gotowej koncepcji duchowości dla swojego Instytutu. Z jednej strony odczuwał głębokie przynaglenie, by odpowiedzieć na pragnienie Jezusa wyrażone w Paray-le-Monial, z drugiej zasięgał opinii o istniejących już zgromadzeniach związanych z kultem Serca Jezusowego i skrupulatnie rozeznawał, czy w nich nie zrealizować swojego powołania ${ }^{22}$.

Odniesienie do przesłania św. Małgorzaty Marii Alacoque w pismach o. Dehona pojawia się natomiast już w projekcie pierwszych Konstytucji z 1881 roku. Jest to koncepcja jasna i wyraźnie umocowana w przekazie Chrystusa z Paray-le-Monial. W tym krótkim dokumencie wyraźnie widać sprecyzowaną ideę wynagrodzenia i zadośćuczynienia Bogu za grzechy. W związku z tym słuszne wydaje się postawienie pytania o wpływ Paray-le-Monial na powstanie samych Konstytucji, ale też i na dalsze życie o. Dehona. Wydaje się, że czynników kształtujących świadomość Założyciela w odniesieniu do kultu Serca Jezusowego było jednak więcej. Zauważmy, że jego życie przypada na okres żywego zainteresowania kultem Serca Jezusowego w ówczesnej Francji. Był to nurt rozwijany na wszystkich możliwych poziomach, takich jak: teologia, liturgia, malarstwo, sztuka oraz praktyki modlitewne.

W celu osadzenia powstałego Zgromadzenia na solidnym fundamencie Tradycji, nauczania Kościoła i teologii o. Dehon dokonuje solidnych studiów duchowości Serca Jezusowego, czego owocem stanie się dwutomowe dzieło pt. Études sur le Sacré Cour de Jésus (Studium o Sercu Jezusowym). W dziele tym Założyciel z mistrzowską precyzją przeprowadza systematyczny wykład duchowości Serca Jezusowego i wszystkiego, co się z nią wiąże. W pierwszym tomie dzieła rozważa on dogłębnie kwestię Serca, poczynając od tradycji starotestamentalnej, poprzez symbolikę wczesnochrześcijańską aż do końca średniowiecza. Natomiast drugi tom poświęcony jest zasadniczo przesłaniu duchowemu św. Małgorzaty

21 Por. tamże.

${ }^{22}$ Por. G. Manzoni, Leon Dehon - człowiek o wielkim sercu, Kraków 1991, s. 93-96. 
Marii Alacoque. Całość rozważań koncentruje się na kwestiach teologicznych, prawnych, liturgicznych oraz praktykach modlitewnych ${ }^{23}$.

Innym czynnikiem, który nakłonił o. Dehona do wejścia w nurt wynagrodzenia, były inspiracje duchowe wyniesione $\mathrm{z}$ domu rodzinnego. Jednym $\mathrm{z}$ najstarszych wspomnień, które zapamiętał młody Leon, były rozmowy matki i ciotek o objawieniach Matki Bożej w La Salette z 1846 roku. Z perspektywy minionych lat nie miał wątpliwości, że istniała zbieżność łącząca ruch wynagradzający z La Salette z jego osobistym powołaniem ${ }^{24}$.

W refleksji nad istotą duchowości opartej na miłości i wynagrodzeniu zasadniczą wydaje się droga rozwoju, którą przeszedł sam Założyciel. Istotną rolę odegrały tu dwie święte kobiety: Małgorzata Maria Alacoque oraz Teresa od Dzieciątka Jezus. Wydaje się, że na podjęcie decyzji o założeniu nowego dzieła objawienia z Paray-le-Monial miały zasadniczy i bezpośredni wpływ. Wezwanie do wynagrodzenia i zadośćuczynienia Bogu za grzechy, w połączeniu z osobistym doświadczeniem niesprawiedliwości społecznej z Saint-Quentin spowodowały wejście w ducha Paray-le-Monial ${ }^{25}$. Szybko jednak w pogłębionej interpretacji tego wymiaru o. Dehon poszerza koncepcję wynagrodzenia, uwzględniając ofiarę składaną na wzór św. Teresy z Lisieux. Kilka miesięcy przed śmiercią zanotował w swoim Dzienniku: „Zrodziliśmy się z ducha św. Małgorzaty Marii, a przybliżamy się do ducha św. Teresy”26.

23 Por. ESC, s. 387-715.

24 Por. H. Dorresteijn, Vita e personalità..., dz. cyt., s. 21.

25 Por. NQT XII, 167-168; Por. S. Gruca, Panie, co chcesz, abym czynit? Teologia powołania kapłańskiego i zakonnego. Studium na podstawie życia i pism Leona Jana Dehona (1843-1925), Kraków 2015, s. 169-171.

26 „Nous sommes nés de l’esprit de Marguerite Marie en nous rapprochant de celui de Sr Thérèse”. NQT XLV/1925, 55. Z powyższej wypowiedzi wynika, że o. Dehon opiera się o koncepcję ofiary i wynagrodzenia przekazaną przez św. Małgorzatę Marię Alacoque, ale bliska jest mu również myśl św. Teresy z Lisieux. Jednak w obydwu przypadkach decydują niuanse. W koncepcji zadośćuczynienia, o którym mówi święta z Paray-le-Monial, odchodzi od wymiaru uczuciowego, a koncentruje się raczej na ofierze z miłości. Natomiast św. Teresa od Dzieciątka Jezus w ofierze akcentuje bardziej oddanie się miłości miłosiernej oraz bierne przyjmowanie krzyży. Tymczasem o. Dehon będzie przeżywał wynagrodzenie Bożemu Sercu za grzechy oraz brak miłości ze strony ludzi. We wszystkich przypadkach zwornikiem jest miłość. Por. S. Gruca, Panie..., dz. cyt., s. 172. 
W początkowym etapie tworzenia norm prawnych dla powołanego do życia Instytutu Oblatów Najświętszego Serca Jezusowego o. Dehon wyraźnie znajdował się bliżej przesłania św. Małgorzaty Marii Alacoque, natomiast w późniejszych pismach widać $\mathrm{z}$ kolei nachylenie w kierunku ducha św. Teresy z Lisieux. W jednym i drugim przypadku nie można jednak mówić o takich samych praktykach. Przywołane odniesienie do dwóch świętych kobiet i ich rola w powstaniu dzieła może sugerować umniejszenie pozycji o. Dehona w jego tworzeniu. Wydaje się, że podobne pytanie pojawiło się już wtedy, gdy Założyciel komentował nowicjuszom pierwszy rozdział Konstytucji. Uważał, że dzieło ma wartość samą w sobie, niezależnie od jakiejkolwiek domieszki charyzmatycznej innych osób. Według niego każdy chrześcijanin winien być ofiarą i oblatem. A w odpowiedzi na pytanie „Kto jest założycielem dzieła?” wskazywał Jezusa: „Serce Jezusa jest naszym Założycielem w znaczeniu teologicznym, ponieważ odkupienie wypływa z Jego Serca, a zatem i wynagrodzenie, które jest jego przedłużeniem. Według św. Gertrudy i św. Małgorzaty Marii, to Serce Jezusa domaga się wynagrodzenia i wzbudza je pod różnymi formami" ${ }^{27}$.

Z powyższych tekstów widać, że o. Dehon pozostawał pod wielkim wpływem ducha św. Małgorzaty Marii Alacoque i w swoim życiu osobistym stosował jej wskazania dla postępu duchowego. Także swoim duchowym synom zalecał prowadzenie osobistego życia duchowego w oparciu o wskazania świętej wizytki. W jednej z medytacji pt. Przyszedłem ogień rzucić na ziemię odwołuje się do św. Małgorzaty Marii Alacoque, która doświadczyła czystej miłości. Następnie zachęca zakonników, żeby pozwolili Jezusowi swobodnie działać ${ }^{28}$. Innym razem wskazuje na świętą jako szczególnie umiłowaną uczennicę Serca Jezusowego, która w przeżywaniu rekolekcji jest dla uczestników po części „matką, albo - jak chcą inni - naszą starszą siostrą" 29 .

${ }_{27}$ Cahiers Falleur, http://www.dehondocsoriginals.org/pubblicati/OEU/CFL (odczyt z dn. 03.05.2020 r.) (dalej: CFL), II, 30-31, por. M. Denis, Projekt..., dz. cyt., s. 34-45.

${ }^{28}$ L. Dehon, Koronki do Najświętszego Serca Jezusowego, t. 1: Wcielenie, Kraków 2018, s. 11 .

29 Tamże, s. 14 
Znacznie mniej odniesień znajdziemy w tekstach normatywnych z początków Zgromadzenia. Pierwsze Konstytucje z 1881 roku w dwóch miejscach wymieniają imię św. Małgorzaty Marii Alacoque. Zaraz po określeniu celu Zgromadzenia, w którym wyraźnie wyczuwa się język z czasów świętej z Paray-le-Monial ${ }^{30}, w$ drugim punkcie opisany jest duch, jaki winien panować w Zgromadzeniu. Ma to być duch gorącej miłości i „czułe nabożeństwo” do Jezusowego Serca, realizowane według wskazań św. Małgorzaty Marii Alacoque, a więc: Komunia Święta wynagradzająca, pierwsze piątki miesiąca i godzina święta. W dalszej części dokumentu święta wizytka wymieniania jest w katalogu patronów Zgromadzenia ${ }^{31}$.

Kolejna redakcja Konstytucji została dokonana w 1885 roku po przywróceniu Zgromadzenia jako Księży Najświętszego Serca Jezusowego. Dokument ten odwołuje się jeszcze do objawień prywatnych, ale już ze słabszym akcentem. Z upływem lat wypowiedzi o. Dehona stają się coraz bardziej teologiczne. Już w prośbie do papieża Leona XIII pisze o specyfice instytutu, który nie jest jednym więcej dziełem poświęconym Sercu Jezusa. Oprócz działalności zewnętrznej, skoncentrowanej na formacji duchowieństwa, misjach i działalności szkolnej, wskazuje również na kapłański i eucharystyczny aspekt wynagrodzenia, jako cechę specyficzną jego Zgromadzenia ${ }^{32}$.

Percepcja myśli św. Małgorzaty Marii Alacoque i jej wpływ na duchowość i kult Bożego Serca realizowane w Zgromadzeniu Księży Najświętszego Serca Jezusowego są wyraźne i głębokie. W spuściźnie piśmienniczej Założyciela istnieje wiele wypowiedzi i komentarzy na ten temat. Wydaje się, że przywołane już wcześniej dwutomowe studium na temat kultu Serca Jezusowego (Études sur le Sacré Cœur de Jésus) stanowi normatywno-teologiczny dokument, streszczający myśl i duchowość

30 „Oblaci Serca Jezusowego mają za cel: uwielbiać Boga, chwaląc, miłując i pocieszając w sposób szczególny Najświętsze Serce Jezusa, by wynagradzać zniewagi czynione temuż Najśw. Sercu, wyrażając swoją skruchę i ofiarując się jako ofiara całopalna na Jego upodobanie, w duchu wynagrodzenia i miłości, jaki jest ich duchem wyróżniającym”. M. Denis, Projekt..., dz. cyt., s. 20.

31 Por. tamże, s. 20-21.

32 Por. tamże, s. 64-67. 
o. Dehona. Już we wprowadzeniu do drugiego tomu, poświęconego przede wszystkim osobie św. Małgorzaty Marii Alacoque i jej przesłaniu, określił on przedmiot kultu Serca Jezusowego. Pisał, że przedmiotem naturalnym tego kultu jest Osoba Chrystusa, a Jego Serce jest przedmiotem specjalnym dla wyrażania pobożności. Dokonuje także rozróżnienia na przedmiot uczuciowy, którym jest cielesne Serce Jezusa oraz przedmiot duchowy, którym jest Boskie Serce Jezusa. W rozdziale dwunastym, poświęconym teologii Serca przestrzega przed poważnym błędem, jakim jest koncentrowanie swojej wiary i pobożności tylko na cielesnym wyobrażeniu Serca. Chociaż przekaz świętej wizytki może do takiej postawy inspirować, to jednak prawdziwy kult musi być kompletny, obejmujący całą osobę Zbawiciela. Serce pojmuje on jako siedlisko cnót i uczuć, zwłaszcza miłości do Ojca i wszystkich ludzi. W Sercu Jezusa koncentrują się wszystkie cierpienia, zwłaszcza doznane podczas męki na krzyżu. Na końcu o. Dehon wskazuje na ranę przebitego boku, która prowadzi do tajemnicy Bożego Serca. Wymownym przewodnikiem rozumienia tej tajemnicy stanie się dla niego św. Jan Apostoł33.

Studium to ukazuje stopniowe dojrzewanie i zdecydowaną autonomię w kształtowaniu ducha i praktyk w oparciu o przesłanie z Paray-le-Monial. Ojciec Dehon nie traktuje wybiórczo elementów nabożeństwa do Serca Jezusowego, ale ujmuje je całościowo, nadając im własną interpretację. Wskazuje też cały szereg nowych praktyk, które nadal podtrzymywane są w tradycji Zgromadzenia. Drogę stopniowej reinterpretacji przesłania św. Małgorzaty Marii Alacoque ukazuje rozdział ósmy. Założyciel mówi w nim o ofiarowaniu się Sercu Jezusa i podaje wskazania świętej wizytki. Następnie poszerza je o szereg czynności, takich jak myśli, wola i zajęcia, które zakonnik wykonuje w ciągu dnia. Kilka stron poświęconych jest Mszy Świętej ku czci Najświętszego Serca Jezusowego, adoracji i Komunii Świętej wynagradzającej. Nową praktyką zalecaną przez niego są nawiedzenia, krótkie adoracje w ciągu dnia, akty strzeliste i koronka do Serca Jezusowego. Potwierdza też praktykę pierwszych piątków miesiąca, godzinę świętą oraz pogłębia kwestie zjednoczenia,

33 Por. ESC, s. 605-607. 
miłości, życia i ofiary z Sercem Jezusa ${ }^{34}$. W przedostatniej części dzieła pt. Kilka wskazań na temat Księży Najświętszego Serca dokonuje ponownej syntezy istotnych elementów duchowości.

\section{Duchowość Serca Jezusowego - „dynamiczna wierność” charyzmatowi Założyciela dzisiaj}

W przywołanym wcześniej studium na temat Serca Jezusowego do istotnych elementów duchowości Zgromadzenia o. Dehon zaliczył m.in.: wynagrodzenie, życie w duchu miłości i ofiary (oblacja, immolacja, postawa żertwy), zjednoczenie z tajemnicami Serca Jezusowego oraz określone formy działalności apostolskiej ${ }^{35}$. Spuścizna duchowa Założyciela na przestrzeni istnienia Zgromadzenia była wielokrotnie komentowana, oczyszczana i dostosowywana do wymogów czasu. Zadanie to nie należy do łatwych, ponieważ adaptacja charyzmatu zderza się z jednej strony z doświadczeniem wiary Założyciela, a $\mathrm{z}$ drugiej - $\mathrm{z}$ trudnością jego ponownego wyrażenia w taki sposób, by nie utracić jego tożsamości. Doświadczenie wiary o. Leona Dehona jest „osobiste” i „wzorcowe”. Jako „osobiste” jest niepowtarzalne i w pewnym sensie nieprzekazywalne, ponieważ jest nacechowane duchem epoki, swoistą formacją rodzinną, społeczną, duchową, środowiskiem, w którym wzrastał, a także własnymi cechami charakteru i temperamentem. Natomiast doświadczenie jest „wzorcowe” w charyzmacie, który przekazał swoim naśladowcom jako pierwszy Oblat Najświętszego Serca Jezusowego. Giuseppe Manzoni, komentując obecne Konstytucje Zgromadzenia, aby zmniejszyć napięcie pomiędzy dziedzictwem Założyciela i jego adaptacją do czasów współczesnych, użył wyrażenia „dynamiczna wierność” ${ }^{36}$. Pojęcie to $\mathrm{w}$ odniesieniu do ducha Założyciela można rozumieć jako wierność charyzmatyczną, a więc wierność Duchowi Świętemu. Według Manzo-

34 Por. ESC, s. 883-993.

35 Por. ESC, s. 689-711.

36 Por. G. Manzoni, Jak $w$ zwierciadle. Konferencje na temat Konstytucji SCJ, Warszawa 1995, s. 8-9. 
niego, „nasza dynamiczna wierność funkcjonuje w oparciu o tajemnicę Chrystusa, tajemnicę i działanie Ducha Świętego, tajemnicę i życie Kościoła w świecie współczesnym" ${ }^{37}$. Do tych tajemnic odnoszą się wartości takie jak: ofiara, adoracja, wynagrodzenie, śluby, życie wspólnotowe i apostolskie zaangażowanie.

Mówiąc o wpływie św. Małgorzaty Marii Alacoque na duchowość Zgromadzenia Księży Najświętszego Serca Jezusowego, należy widzieć ją również w kategorii „dynamicznej wierności”. Istotne elementy kultu Serca Jezusowego, osadzone w dziedzictwie Kościoła, zostały wyeksponowane w XVII wieku przez apostołkę Bożego Serca. Następnie te elementy, pogłębione i umocnione na płaszczyźnie teologii, zostały przeżyte w osobistym doświadczeniu wiary o. Dehona i urzeczywistnione w charyzmacie sercańskim.

Odczytując dzisiaj Konstytucje Zgromadzenia, można odnieść wrażenie, że niewiele jest tam wyrażeń charakterystycznych dla o. Dehona i jeszcze mniej odwołujących się do św. Małgorzaty Marii Alacoque. Dopiero głębsza analiza, uwzględniająca dynamikę czasu, historii i teologii odsłania bogactwo dokumentu. Wydaje się, że kluczem do zrozumienia dzisiaj istotnych elementów przesłania z Paray-le-Monial w duchowości Zgromadzenia jest słowo „kontemplacja” i „otwarty bok”. Nabożeństwo do Serca Jezusowego rodzi się z kontemplacji miłości objawionej w przebitym boku. Praktyka kontemplacji jest czymś więcej od fizycznego spojrzenia. Jest wniknięciem ducha, aby uwierzyć, czyli przylgnąć całą osobą do Jezusa. Mistrzem w tym względzie jest św. Jan Ewangelista. Jego pełne miłości spojrzenie jako umiłowanego ucznia jest przepełnione wiarą. Nie jest ono czysto zewnętrzne, ale sięgające serca. Święta Małgorzata Maria Alacoque pierwsze objawienie Jezusa przeżyła we wspomnienie św. Jana Ewangelisty. Pisała, że przez kilka godzin spoczywała na piersi Jezusa. W relacji z doznanych przeżyć wspominała o boku Jezusa, z którego wydobywały się promienie. Motyw promieni, które powoli prowadzą ją przez otwarty bok do Serca, jest obecny także w drugim objawieniu. Dla o. Dehona również kontemplacja boku Jezusa nie

37 Tenże, Katechizm wprowadzający do nowych Konstytucji, Kraków 1992, s. 14-15. 
mogła pozostać tylko zewnętrznym spojrzeniem, ale stała się dla niego wejściem w tajemnicę Bożej miłości. W obecnych Konstytucjach nie ma żadnej wzmianki o św. Małgorzacie Marii Alacoque ani o jej wizji, ukazującej Serce Jezusa otoczone cierniami i krzyżem. Nie oznacza to umniejszenia opatrznościowej i doniosłej roli świętej z Paray-le-Monial, lecz wskazuje raczej na wierność Tradycji Kościoła. Jej symbolem pozostaje tutaj św. Jan Apostoł. W obecnym tekście Konstytucji doświadczenie wniknięcia w najgłębszą rzeczywistość miłości Boga zostało ujęte następująco: „Razem ze św. Janem w otwartym boku Ukrzyżowanego widzimy znak miłości, która przez całkowity dar z siebie samej na nowo stwarza człowieka według Boga" ${ }^{38}$.

Innym istotnym sposobem wyrażenia duchowości sercańskiej, zaczerpniętym z Paray-le-Monial, jest wynagrodzenie. Jezus pragnął od św. Małgorzaty Marii Alacoque, aby przynajmniej ona starała się wynagradzać za obojętność i odwrócenie się od okazanej miłości. Chrystus wskazuje na praktyki duchowe, a więc modlitwę i częstą Komunię Świętą wynagradzającą, przyjmowaną zwłaszcza w pierwszy piątek miesiąca. Ważnym elementem wynagrodzenia jest przyjmowanie krzyży i przeżywanie cierpienia w zjednoczeniu z Jego Sercem ${ }^{39}$. W obecnych Konstytucjach Zgromadzenia temat wynagrodzenia ma charakter bardziej teologiczny. W 23. numerze dokumentu czytamy: „Przez wynagrodzenie rozumiemy więc: przyjęcie Ducha Świętego, odpowiedź na miłość Chrystusa względem nas, ścisłą łączność z Jego miłością ku Ojcu oraz współpracę z Jego zbawczym dziełem w świecie”. W kolejnych numerach jest mowa o uwalnianiu ludzi od grzechu, trosce o jedność i prowadzenie apostolatu w duchu wynagrodzenia.

Ważnym tematem w Konstytucjach, wyrażonym współczesnym językiem, jest kwestia cierpienia. Ma być ono ofiarowane i znoszone z cierpliwością oraz całkowitym zdaniem się na Boga. Nawet pośród ciemności

${ }^{38}$ Reguła życia Zgromadzenia Księży Najświętszego Serca Jezusowego (Księża Sercanie). Konstytucje i Dyrektorium generalne, Rzym 2009 (dalej: Konst.), 21. Por. G. ManzoNI, Jak w zwierciadle..., dz. cyt., s. 158-162. Por. także: M. M. Wóðcıк, Pan jej objawił tajemnicę swego Serca. Święta Małgorzata Maria Alacoque, Jasło 2003, s. 61-65.

39 Por. M. M. Wóıcıк, Pan jej objawił..., dz. cyt., s. 66-70. 
i samotności staje się wynagrodzeniem i czymś wzniosłym w połączeniu z cierpieniami i śmiercią Chrystusa dla zbawienia świata ${ }^{40}$. Tak ujęte wynagrodzenie wpisuje się z pewnością w nurt „dynamicznej wierności” charyzmatowi o. Dehona. Według niego wynagrodzenie zawsze skierowane jest ku Chrystusowi i wraz z Sercem Chrystusa ku Ojcu. W tekstach Założyciela wynagrodzenie zastępowane było takimi określeniami, jak „pocieszenie”, „zadośćuczynienie”, „odpowiedź na miłość” i „bycie żertwą". Pojęcia te bliskie są językowi używanemu przez św. Małgorzatę Marię Alacoque. W późniejszych pismach Założyciela widać pewną zmianę. Chociaż jego wierność Paray-le-Monial pozostawała niezmienna, dokonywał jednak refleksji teologicznej opartej o Pismo Święte, dotyczącej natury, możliwości i skuteczności wynagrodzenia w perspektywie odkupienia. Doszedł do przekonania, że jego wynagrodzenie jest ponoszeniem ofiar i jednoczeniem się z Jezusem, który kontynuuje swoje dzieło zbawcze. Wydaje się, że ten sposób rozumowania o. Dehona dobrze uzasadnia koncepcję wynagrodzenia z dzisiejszych Konstytucji, pojmowanego jako odpowiedź na miłość, jednoczenie się z uczuciami Jezusa oraz współpracę w zbawczym dziele Ojca ${ }^{41}$.

Mocno rozwiniętą kwestią w charyzmacie o. Dehona i duchowości księży sercanów jest również aspekt ofiary. Pod tym względem Założyciel inspiruje się również przeżyciami i słowami przekazanymi przez św. Małgorzatę Marię Alacoque. W ich interpretacji idzie jednak głębiej, dochodząc do teologii opartej na jedynej ofierze zbawczej złożonej przez Chrystusa. Jezus jest tym, który składa ofiarę, i tym, który jest składany w ofierze. Święta wizytka aspekt ofiary postrzegała raczej w wymiarze osobistym, jako znoszenie i składanie Bogu swoich cierpień, które On dopuszczał w jej życiu. Sam Jezus wielokrotnie o tym jej mówił. O konieczności ponoszenia ofiar w ciągu życia święta przekonała się po doświadczeniu wizji Trójcy Świętej. W objawieniu tym Bóg Ojciec zapowiedział, że da jej ten sam krzyż, jaki ofiarował swojemu Synowi. Jezus obiecał, że przymocuje ją do krzyża w taki sposób, w jaki sam był

\footnotetext{
40 Por. Konst. 24.

41 Por. G. Manzoni, Jak w zwierciadle..., dz. cyt., s. 217-220.
} 
do niego przybity. Duch Święty jako Miłość zapewnił ją, że dokończy dzieła przez jej wyniszczenie i oczyszczenie. Z czasem św. Małgorzata Maria Alacoque zrozumiała, że była to zapowiedź życia duchem ofiary ${ }^{42}$.

Ojciec Dehon w dniu składania profesji zakonnej (28 czerwca 1878 roku), oprócz trzech ślubów: czystości, ubóstwa i posłuszeństwa, złożył prywatny ślub żertwy. Pragnął również, żeby ten sam ślub składali wszyscy zakonnicy. W pierwszych Konstytucjach z 1881 roku zalecił: „Oblaci składają zwykłe śluby zakonne, do których dołączą czwarty ślub, przez który ofiarują się Sercu Jezusa jako żertwy przebłagania i miłości" ${ }^{43}$. Nowicjuszom wyjaśniał, że ten typ ofiary należy wyrażać najpierw na poziomie praktyk zakonnych. Głębszą jego formą będzie zupełne zdanie się na wolę Boga, nie tylko poprzez bierne przyjmowanie cierpień, ale przez powierzenie Bogu całego siebie i tego, co się posiada ${ }^{44}$.

\section{Zakończenie}

Objawienia Najświętszego Serca Jezusowego w Paray-le-Monial należą do sfery objawień prywatnych. Zostały jednak oficjalnie potwierdzone przez Kościół i przyczyniły się do rozwinięcia i ugruntowania duchowości Serca Jezusowego. Natura zjawisk opisywanych przez św. Małgorzatę Marię Alacoque pozostaje wciąż dla nas tajemnicza i nieuchwytna, ponieważ dotyczy rzeczywistości duchowej znanej samemu Zbawicielowi i duszy, w której On działa. Doświadczenie, które nam przekazała święta z Paray-le-Monial, jest jej własnym przeżyciem, nacechowanym osobistym sposobem myślenia, językiem i kulturą, w której wzrastała. Pomijając jednak to, co w tym przesłaniu jest drugorzędne, można również dzisiaj dostrzec jego bogactwo, prowadzące do miłości Bożego Serca. Doświadczenie takie przeżył sługa Boży o. Leon Dehon, Założyciel Zgromadzenia Księży Najświętszego Serca Jezusowego, który ubogacony we własne doznanie Bożej miłości odkrył i zrealizował swoje powołanie założycielskie.

\footnotetext{
42 Por. M. M. Wóıciк, Pan jej objawił..., dz. cyt., s. 68-69.

${ }^{43}$ M. Denis, Projekt..., dz. cyt., s. 22-23.

${ }_{44}$ Por. CFL V, 93.
} 
Tym, co najbardziej czyni podobnym do siebie św. Małgorzatę Marię Alacoque i o. Leona Dehona, jest miłość do Serca Jezusowego i ogromne pragnienie zrealizowania woli Bożej w ich osobistym życiu. Święta wizytka po wielu trudach, ofiarach i głębokim rozeznawaniu zobaczyła powolne spełnianie się pragnienia Jezusa o miłości zalewającej świat. Zdumiewająca jest również wytrwałość o. Dehona, zmierzająca do założenia nowego instytutu o charakterze wynagradzającym. Doświadczenie wiary, rozeznanie duchowe, jak również szerokie konsultacje z ówczesnymi założycielami innych zgromadzeń zakonnych doprowadziły go do założenia dzieła, w którym przesłanie z Paray-le-Monial znajduje swoją aktualizację i pogłębienie.

\section{Bibliografia}

Alacoque M. M., Listy św. Małgorzaty Marii Alacoque, tłum. M. K. Piwnicka-Bohuszewicz, Kraków 2009.

Alacoque M. M., Pamiętnik duchowy, Kraków 2003.

Benedykt XV, Przedziwna historia. Bulla kanonizacyjna bł. Małgorzaty Marii Alacoque, dziewicy, siostry profeski Zakonu Nawiedzenia Najświętszej Maryi Panny, Kraków 2017.

Cahiers Falleur, http://www.dehondocsoriginals.org/pubblicati/OEU/CFL (odczyt z dn. 03.05.2020 r.).

Dehon L., Études sur le Sacré Cœur de Jésus, w: L. Dehon, Euvres Spirituelles, t. 5, Andria 1984, s. 387-715.

Dehon L., Koronki do Najświętszego Serca Jezusowego, t. 1: Wcielenie, Kraków 2018.

Dehon L., La revue catholique des idées et des faits, Benoît XV intime, 10 février 1922 r., http://www.dehondocsoriginals.org/pubblicati/ART/REV/ARTREV-1922-0200-0004309?ch=10 (odczyt z dn. 02.05.2020 r.).

Dehon L., Lettres circulaires, http://www.dehondocsoriginals.org/pubblicati/ COR/LCC (odczyt z dn. 02.05.2020 r.).

Dehon L., Notes quotidiennes, http://www.dehondocsoriginals.org/pubblicati/ JRN/NQT (odczyt z dn. 02.05.2020 r.). 
Dehon L., Notes sur l'histoire de ma vie, http://www.dehondocsoriginals.org/ pubblicati/JRN/NHV (odczyt z dn. 03.05.2020 r.).

Dehon L., Euvres Spirituelles, t. 5, Andria 1984.

Denis M., Projekt o. Dehona, Kraków 1990.

Dorresteijn H., Vita e personalità di Padre Dehon, Bologna 1978.

Drążek C., Grzebień L. (red.), Bóg bliski. Historia i teologia kultu Najświętszego Serca Jezusa, Kraków 1983.

Gruca S., Panie, co chcesz, abym czynit? Teologia powołania kapłańskiego i zakonnego. Studium na podstawie życia i pism Leona Jana Dehona (1843-1925), Kraków 2015.

La glorificazione della B. Margherita Alacoque e la propagazione del culto del S. Cuore, „La Civiltà cattolica” 1(69) (1918), s. 143-148.

Manzoni G., Jak w zwierciadle. Konferencje na temat Konstytucji SCJ, Warszawa 1995.

Manzoni G., Katechizm wprowadzajacy do nowych Konstytucji, Kraków 1992.

Manzoni G., Leon Dehon - człowiek o wielkim sercu, Kraków 1991.

Reguła życia Zgromadzenia Księży Najświętszego Serca Jezusowego (Księża Sercanie). Konstytucje i Dyrektorium generalne, Rzym 2009.

Wójcik M. M., Pan jej objawił tajemnicę swego Serca. Święta Małgorzata Maria Alacoque, Jasło 2003.

Ks. dr Stanisław Gruca - sercanin, pochodzi z Binczarowej (diecezja tarnowska). Tytuł magistra teologii uzyskał na Wydziale Teologicznym Papieskiej Akademii Teologicznej w Krakowie na podstawie pracy magisterskiej pt. Dzieje miejscowości i parafii Binczarowa, napisanej pod kierunkiem ks. prof. dr. hab. Jana Związka. Ukończył kurs formatorów i studium życia konsekrowanego w Rzymie. Doktorat z teologii duchowości uzyskał na Katolickim Uniwersytecie Lubelskim Jana Pawła II na podstawie rozprawy pt. Teologia powołania kapłańskiego i zakonnego. Studium na podstawie życia i pism Leona Jana Dehona (1843-1925), napisanej pod kierunkiem s. prof. dr hab. Teresy Paszkowskiej. 